ARGONNE NATIONAL LABORATORY

9700 South Cass Ayenue, Argonne, Illinois 60439

ANL/EES-TM--331

ANL/EES-TM-33i

DE87 009995

\title{
REVIEW OF RADIOLOGICAL SURVEYS OF THE \\ GENERAL SERVICES ADMINISTRATION'S \\ RARITAN DEPOT IN EDISON, NEW JERSEY
}

October 1986

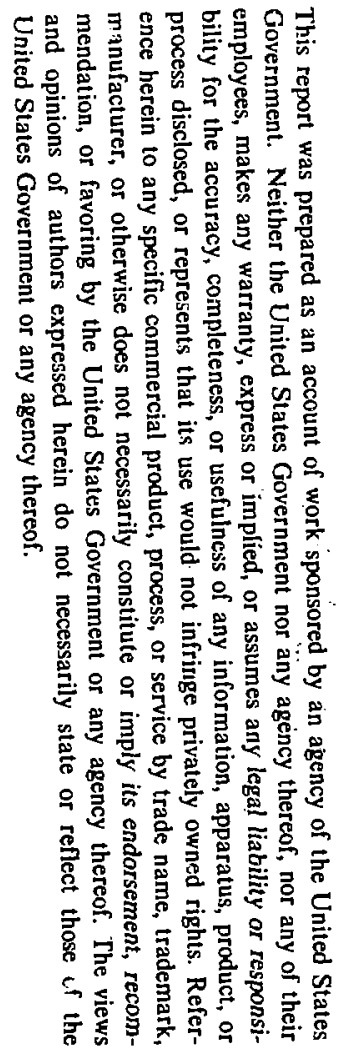

work sponsored by

\section{U.S. ARMY CORPS OF ENGINEERS}

Huntsville, Alabaina

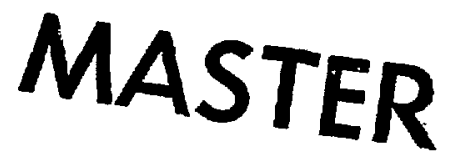




\section{CONTENTS}

Introduction $\ldots \ldots \ldots \ldots \ldots \ldots \ldots \ldots \ldots \ldots \ldots \ldots \ldots \ldots \ldots \ldots \ldots \ldots \ldots \ldots \ldots \ldots, 1$

Direct Measurements of Gamma Radiation $\ldots \ldots \ldots \ldots \ldots \ldots \ldots \ldots \ldots \ldots \ldots$. 1

Measurements of Radon and Radon Decay Products $\ldots \ldots \ldots \ldots \ldots \ldots \ldots \ldots \ldots$ 4

Sampling of Building Materials and Their Radionuclide Content $\ldots \ldots \ldots \ldots \ldots \ldots, 7$

Detailed Comments and Criticisms $\ldots \ldots \ldots \ldots \ldots \ldots \ldots \ldots \ldots \ldots \ldots \ldots \ldots, \quad 7$

Recommendations $. . \ldots \ldots \ldots \ldots \ldots \ldots \ldots \ldots \ldots \ldots \ldots \ldots \ldots \ldots \ldots, 8$

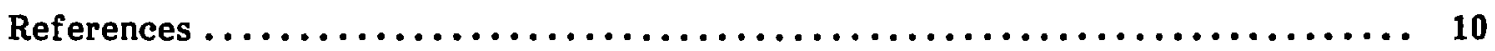

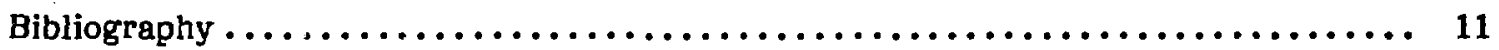

Appendix: Inhalation Dose from Radon Decay Products in Bldg. 205........... 12

\section{TABLES}

1 Results of EPA and NUS Radiological Survey of Raritan Depot $\ldots \ldots \ldots \ldots \ldots \ldots$. 5

2 Radon Guidelines and Standards $\ldots \ldots \ldots \ldots \ldots \ldots \ldots \ldots \ldots \ldots \ldots \ldots \ldots \ldots$

\section{FIGURES}

1 Location of Raritan Depot................................... 2

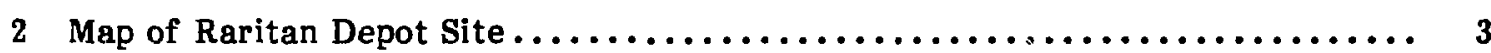




\title{
REVIEW OF RADIOLOGICAL SURVEYS OF THE GENERAL SER VICES ADMINISTRATION'S RARITAN DEPOT IN EDISON, NEW JERSEY
}

by

\author{
C.L. Herzenberg and R.C. Winter
}

\section{INTRODUCTION}

This report reviews two recent radiological surveys of the General Services Administration (GSA) Raritan Depot in Edison, New Jersey, that were conducted after somewhet elevated levels of radiation were detected within a depot building. The depot location and layout are shown in Figs. 1 and 2.

The first survey was conducted January $6-8,1986$, by the NUS Corporation; ${ }^{1}$ it indicated gamma radiation levels were higher than natural background levels in some buildings and identified the probable source of the radiation as gypsum-like building tiles - iet contained natural uranium-chain radionuclides at a level 20 times higher than other materials. Elevated levels of radon and radon decay products also were detected in some buildings.

A follow-on survey was conducted April 28-May 2, 1986, by the U.S. Environmental Protection Agency (EPA), Office of Radiation Programs. ${ }^{2}$ This survey was designed to confirm the January measurements and to measure radiation levels at other locations: additional buildings at the depot, buildings on the Middlesex County College campus, and a possible outdoor disposal site.

The EPA measurements established that ceiling material is the primary source of the radiation. Radioisotope analysis of the ceiling tile material from buildings with elevated radiation levels showed the presence of radium-226 at levels of approximately 25 picocuries per $\mathrm{gram}(\mathrm{pCi} / \mathrm{g}$ ); this material would thus have to be treated as hazardous waste, should it be removed. ${ }^{2}$ The maximum concentrations of radon and radon decay products found in the EPA survey exceed the guidelines for residential exposure established by the EPA and Centers for Disease Control (CDC), but, apart from a single measurement, are lower than the U.S. mining occupational standards for radon.

This report critiques the methodology and results of the two surveys and recommends further action.

\section{DIRECT MEASUREMENTS OF GAMMA RADIATION}

Gamma radiation was measured directly inside about half of the buildings examined, using portable survey instruments. Of these buildings, only two were surveyed using a systematic detailed methodology with grid systems (by NUS); the other buildings were checked in a more cursory fashion (by NUS and/or EPA). 

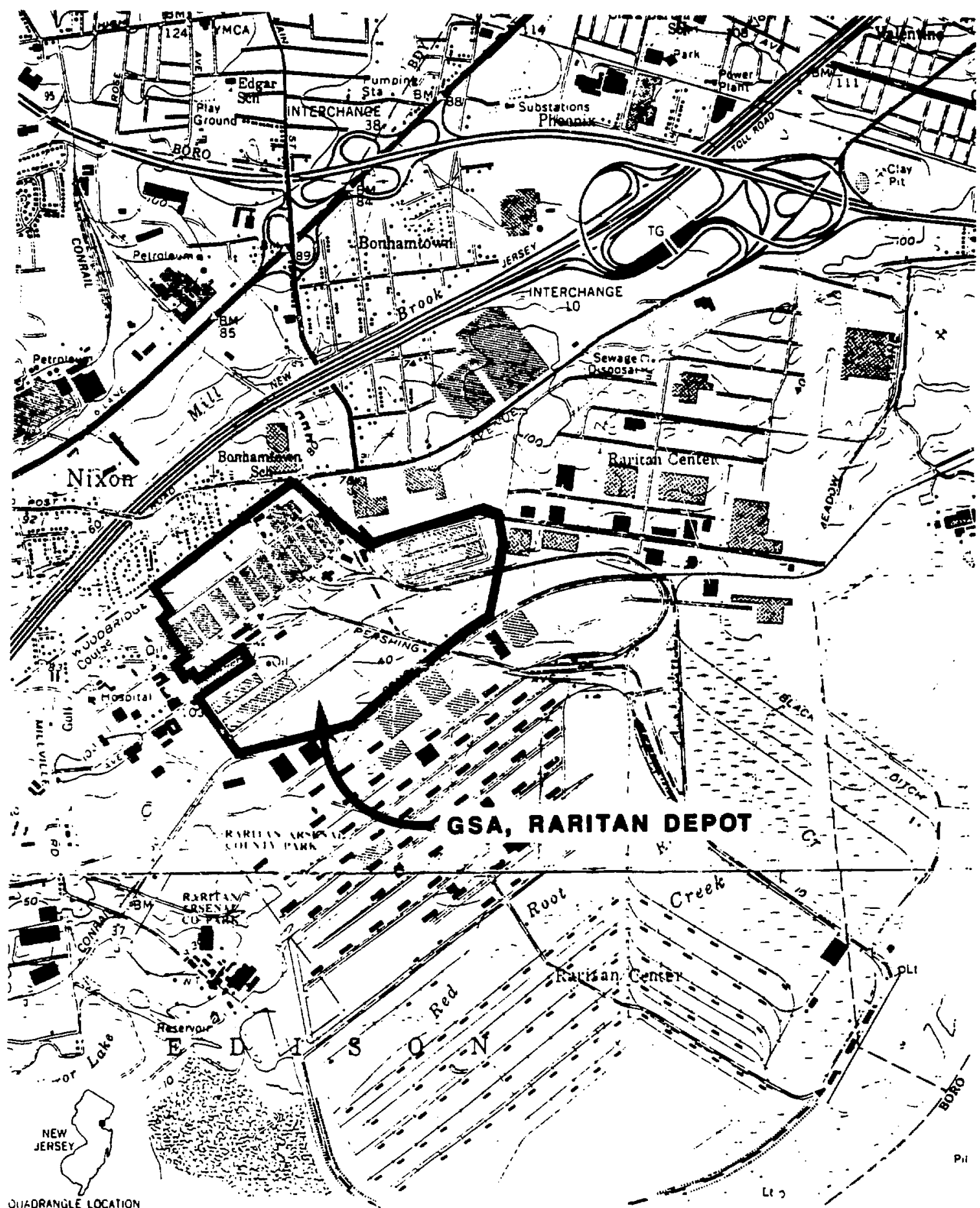
DiLORANGLE LOCATION

IOUADIPEATK AMBOYISOUTH AMBOY, N.J.

FIGURE 1 Location of Raritan Depot (Source: Ref. 1) 




FIGURE 2 Map of Raritan Depot Site (Source: Ref. 1; not to scale) 
Direct gamma radiation levels measured on site ranged from 5 to 24 microroentgens per hour $(\mu \mathrm{R} / \mathrm{h})$, as shown in Table 1 . The lower values correspond to the natural radiation background level. However, the gamma radiation levels measured inside at least seven buildings clearly exceed natural background. External roof top measurements also indicated clearly elevated levels of ambient gamma radiation at those and other buildings.

The highest gamma dose rate reported inside any building, $24 \mu \mathrm{R} / \mathrm{h}$, corresponds to an annual dose of about 210 milliroentgens (mR) assuming 24-h/day, 365-day/yr occupancy; this dose is well below the maximum permissible dose limit of $500 \mathrm{mR} / \mathrm{yr}$ for the general population. Thus, it would appear on the basis of measurements to date that the gamina radiation in the surveyed buildings at the GSA Raritan Depot does not present any hazard.

\section{MEASUREMENTS OF RADON AND RADON DECAY PRODUCTS}

Measurements of radon concentrations in air were reported for only 3 of the 37 buildings examined in the two surveys, and measurements of radon decay products were reported for only 5 buildings (Table 1). The reported radon concentrations in air ranged from 0.4 to 4.6 picocuries per liter $(\mathrm{pCi} / \mathrm{L}$ ), and concentrations of radon daughter products ranged from less than 0.001 to 0.083 working level (WL).*

For comparison purposes, radon guidelines and standards are shown in Table 2. 3-8 While there are no specific limits for occupational exposures to radon or its decay products for nonradiation workers, ${ }^{2}$ the EPA has set guidelines for residential exposure; these guidelines suggest taking action if radon concentrations exceed $4.0 \mathrm{pCi} / \mathrm{L}$ or radon decay product concentrations exceed $0.02 \mathrm{WL} .2,9,10$ These guideilines for residential buildings are based on occupancy $75 \%$ of the time. If occupancy only during a 40-hr work week is assumed, higher exposure rates during working hours could be tolerated to produce the same integrated dose; these values would be $13 \mathrm{pCi} / \mathrm{L}$ and $0.06 \mathrm{WL}$. However, there is to our knowledge no regulatory formalization of values such as these, although they might be deemed reasonable criteria in view of the EPA guidelines for residential buildings. All of the reported levels of radon and radon daughter products are below the U.S. mining occupational standards (Table 2), apart from a single reading from Bldg. 205 that is marginally higher $(0.083 \mathrm{WL}$ compared to 0.080 WL).

The highest levels of radon and its decay products were found in the air of Bldg. 205. The corresponding radiation dose to an occupant inhaling this air is evaluated in the appendix. ${ }^{11}$ Full-time exposure would lead to an annual dose of nearly 5 rem, while exposure only during a 40-h work week would lead to an annual dose of about 1.2 rem.

\footnotetext{
*The working level, WL, is any combination of short-lived radon decay products in $1 \mathrm{~L}$ of air that will result in the ultimate emission of alpha particles with a total energy of 130 billion electron volts. Working level is a measure of the concentration of radioactivity in the air, not of how much radiation a person actually receives.
} 


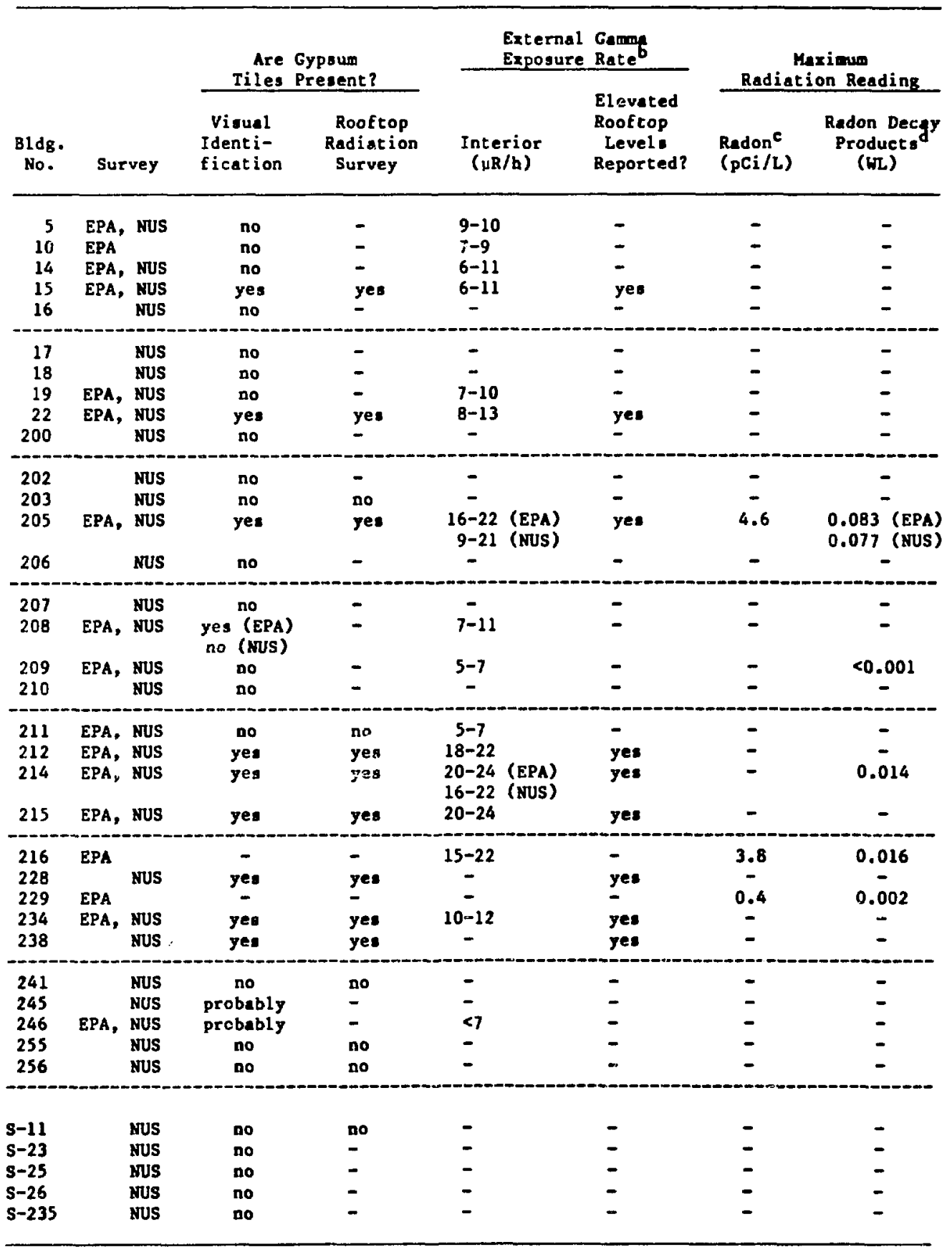

a - indicates no radiation measurement or visual survey finding was reported.

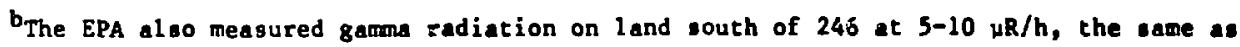
natural background levels.

CThe EPA-CDC guideline for maximum residential exposure to radon in air it $4.0 \mathrm{pCi} / \mathrm{L}$.

dThe EPA-CDC guideline for maximum residential exposure to radon decay products is

$0.02 \mathrm{WL}$; the natural background level is $0.001 \mathrm{WL}$. 


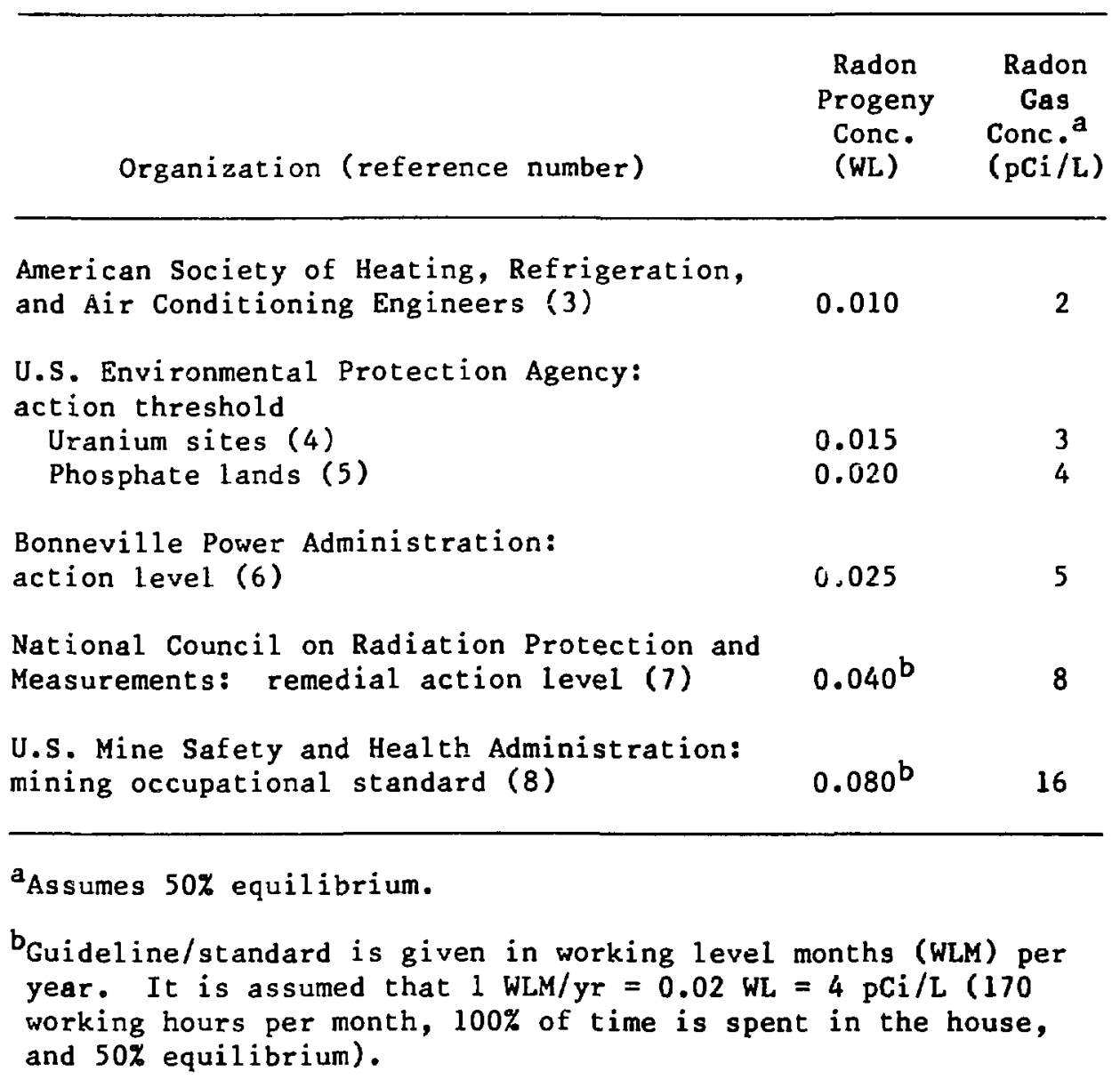

By comparison, in Bldg. 205, the highest reported dose rate of external gamma radiation, $22 \mu \mathrm{R} / \mathrm{h}$, would give a 24-h/day occupant an annual dose of about $190 \mathrm{mrem}$. Thus, to the extent that a radiation hazard exists, it is from inhalation of radon and its decay products in the air of the building, not from gamma radiation emitted from building materials.

It is helpful to compare levels of radon and its daughter products at the depot and other locations. While insufficient data exist to define an average residential level of radon in air, a reasonable assumption is about $1 \mathrm{pCi} / \mathrm{L} .12$ Based on limited testing, the EPA has estimated that the guidance level for radon in air of $4 \mathrm{pCi} / \mathrm{L}$ is exceeded in about $12 \%$ of houses in the U.S., that is, in about 8 million houses. 9 However, the guidance levels of $4 \mathrm{pCi} / \mathrm{L}$ for radon, or $0.02 \mathrm{WL}$ of radon daughter products, were established more as practical goals than because of any absolute degree of safety; ${ }^{10}$ these guidance levels still permit an estimated lifetime increased risk of lung cancer due to exposure of about 1 in $100.10,12$ 


\section{SAMPLING OF BUILDING MATERIALS AND THEIR RADIONUCLIDE CONTENT}

Material samples were collected on site by both the EPA and NUS teams and subsequently analyzed for radionuclide content by gamma spectrometry. Samples were taken of gypsum-type ceiling tiles (gypsum-like roofing material), other roofing material (built-up roofing and roofing rock), concrete from the floor, soil, paint, brick, and other materials from the buildings. Analyses using gamma spectrometry (and, in some instances, alpha detection) were reported for 13 samples.

Direct measurements of gamma radiation near the ceiling tiles had already indicated that ceiling material is the primary source of gamma radiation in the buildings. The radioisotopic analyses of the building materials indicate that the source of the elevated levels of gamma radiation, radon, and radon daughter products in the buildings examined is naturally occurring uranium-238 chain radionuclides in the gypsumlike roofing (ceiling tile) material.

All material samples other than the gypsum-like ceiling tiles exhibited radium226 concentrations of about $1.3-1.5 \mathrm{pCi} / \mathrm{g}$, not much higher than typical background concentrations in soils of about $1 \mathrm{pCi} / \mathrm{g}$ (radium-226 is a key member of the uranium series immediately preceding radon in the decay chain). However, the reported radium226 concentrations in various ceiling tile samples ranged from 24 to $40 \mathrm{pCi} / \mathrm{g}$. (The NUS radiochemical analyses for the tiles gave systematically higher concentrations, about $10 \%$ higher for lead-214 and bismuth-214, than did the corresponding EPA analyses.) Thus, the ceiling tiles exhibit 20-40 times more natural radioactivity than do typical surface soils or other building materials for which analyses were reported. For perspective, the concentration of radium-226 in these tiles is 15-35 times lower than the concentrations typical of uranium processing waste. 1

Although the EPA and NUS reports do not address the question of the nature and chemical composition of the gypsum-like tiles, this question is relevant both to measurement methods and to the wider issues of origin and possible further low-level contamination at these buildings and other buildings at the Raritan Depot and other sites. 13 Available evidence suggests that the material in these so-called "gypsum-like tiles" is very likely phosphate slag, phosphogypsum, or a very similar material. Dependent upon origin, by-product gypsums exnibit radon-226 concentrations varying by a factor of $\mathbf{3 0}$ or more: some gypsums from apatite exhibit radium-226 concentrations near background levels $(0.7 \mathrm{pCi} / \mathrm{g}),{ }^{14}$ while gypsums from phosphorite deposits exhibit concentrations in the range of $16-25 \mathrm{pCi} / \mathrm{g}$, with phosphogypsum from Florida at the high end. 13,14 Phosphogypsum is a waste product of the phosphate industry (notably in Florida) and has been used as a building material. 13,14 Difficulties with radon from gypsum wallboard and other phosphogypsum building materials have been reported previously, but this case of ceiling tiles is unique in our experience. 11,13

\section{DETAILED COMMENTS AND CRITICISMS}

Both the EPA and the NUS radiation surveys appear to have been competently conducted on the whole, although both had limitations. A major limitation is that, for many buildings, not even a cursory radiological survey was reported -- only visual 
inspection for gypsum-type tiles. While the EPA survey made quantitative radiological measurements in more buildings than did the NUS survey, interior measurements were not made in all buildings (see Table 1).

The NUS survey made detailed external gamma measurements on a grid system within two buildings, rather limited gamma measurements in some additional buildings, and measurements of radon decay products in only two buildings. The NUS roof top radiation survey used different instruments at different buildings, with results reported only in terms of counting rates; because of the different sensitivities and background levels of the instruments, an overall comparison of roof top radiation levels of various buildings is difficult.

While most buildings were inspected visually for the presence or absence of gypsum-type tiles, unambiguous visual results were not obtained for all cases. For Bldgs. 245 and 246, for example, "possible positive" (not "positive") identification was made by the NUS survey, but the EPA survey did not confirm or rule out the presence of radioactive tiles. In addition, in Bldg. 208, the EPA's visual identification of ceiling tile material disagreed with the reported NUS identification.

Since the only radiological problem of any significance in any of the buildings seems to be from radon and its decay products, it is somewhat surprising that so few radon or radon decay product measurements were made in either survey. In the NUS survey, RPISU (radon progeny integrating sampling unit) measurements for working levels of radon decay products were made in only two buildings. The EPA survey took grab sample and/or RPISU measurements in four buildings and measured the radon concentration in air using charcoal canisters in those buildings. However, the levels of radon and radon decay products in the air of other buildings that incorporate radioactive gypsum-tile materials remain unknown.

It appears that these measurements of radon and its daughter products could have been supplemented by collecting and analyzing grab samples in other buildings (e.g., by use of a Gilian high-flow sampler with readout on an EDA Instruments, Inc., portable photomultipler-scaler, which could have permitted on-the-spot measurements within all accessible buildings). Longer-term integrating measurements could have been started by emplacing other types of integrating detectors, such as track-etch polycarbonate plastic

detectors. We mention this because charcoul canisters are subject to errors from a variety of different causes (e.g., exposure to moisture or organic vapors). Furthermore, since radon levels, particularly in structures built of phosphogypsum, can exhibit large short-term fluctuations (by more than a factor of 10 ), longer-term measurements would be desirable. ${ }^{13}$

\section{RECOMMENDATIONS}

Clearly a range of options exists to deal with the problem of elevated radiation levels in the GSA Raritan Depot buildings. These options include demolition of some buildings (e.g., those with elevated radiation levels for which no future use is anticipated), employment of various control measures, or use of mitigative measures that have been developed for coping with radon in building air that results from the presence 
of radionuclides in building materials. ${ }^{15}$ For some buildings, no action would be required. Measures designed for the specific control of indoor radon originating from soil diffusion into basements would not be appropriate for use in the depot buildings, except to the extent that the soil may make some minor contribution to the indoor radon concentration in these buildings. ${ }^{16,17}$

A more comprehensive radiation survey of the depot buildings should be considered, for two reasons: (1) to establish unambiguously the location of all building materials with elevated levels of radioactivity and of any other radioactive materials on site and (2) to determine the extent of any health hazard presented by these materials. In addition, the source of the gypsum-type tiles should be identified if records still exist, and other installations that might have used similar tiles in buildings should be informed of the potential problem. Specific recommendations in three areas are presented below.

Gamma Radiation Measurements. External gamma exposure rates should be measured in every building to establish whether ambient gamma radiation levels are above background levels. (The NUS and EPA surveys measured interior gamma exposure rates in only about half of the buildings examined; see Table 1.) Roof top counting rate measurements have indicated the presence of radioactivity inside some buildings in which no interior measurements were made. In addition, visual inspection has suggested the presence of radioactive ceiling tiles inside some buildings for which no interior measurements were made. The NUS and EPA surveys disagreed on visual identification of tiles in at least one building (208); such ambiguities should be definitively resolved. Since the roof top survey used several different instruments with differing sensitivities and background counting rates, and since results were reported only as counting rates, quantitative comparison among the nine buildings with elevated readings is difficult. In all cases, ceiling tile materials in place should be checked for elevated activity levels by measuring gamma radiation flux adjacent to the tiles. These procedures should be conducted systematically and fully documented, so that ambient gamma radiation levels within each building are known and so that the location and quantity of all ceiling tiles with elevated levels of radioactivity on the site are documented. It is, however, probably not necessary to conduct further detailed grid surveys of the type undertaken by NUS for Bldgs. 205 and 214.

Radon Measurements. As mentioned earlier, to the extent that any radiation health hazard exists in these buildings, it originates from radon and radon decay products that have outgassed from the ceiling tiles and are present in the interior air of the buildings. However, to date, measurements have been reported for radon and/or radon decay products inside only five buildings. It would be prudent to make such measurements in all buildings for which further use is anticipated, for several reasons. Of the five buildings for which such measurement have been made, two exhibit levels of radon and radon decay products that approach or exceed EPA guidelines, as discussed earlier. Thus it seems highly probable that radon concentrations are elevated in additional buildings at the depot. In addition, radon levels in air exhibit seasonal and diurnal variations of at least a factor of 10 and are also sensitive to building ventilation, temperature, and relative humidity. ${ }^{11,13}$ Thus, a more extensive program for measuring 
the levels of radon and its decay products would help ensure that those levels do not greatly exceed the values already measured.

Radioisotopic Analyses. There does not appear to be a need for further radioisotopic analyses of material samples, since the evidence from the surveys indicates that the only material in the buildings with radioactivity levels much above background levels is the gypsum-type ceiling tile. Based on the fairly consistent activity level of radium-226 in the tiles analyzed, and our tentative identification of the tile material as being of phosphogypsum composition, we would not expect any drastically higher concentrations of radioactivity to be found in other tile material.13 of course, if radiation surveys of the remaining buildings turned up other types of radioactive materials, radioisotope analysis would be desirable.

\section{REFERENCES}

1. F'inal Draft Report on Radiation Survey of Buildings in the GSA Raritan,Depot, Edison, New Jersey, NUS Corp. Report R-584-01-86-03 for the U.S. Environmental Protection Agency (March 17, 1986).

2. A Radiological Survey of the GSA Raritan Depot, Edison, New Jersey, April 28May 2, 1986 (draft report), U.S. Environmental Protection Agency, Office of Radiation Programs, Eastern Environmental Radiation Facility, Montgomery, Ala. (1986).

3. Ventilation for Acceptable Indoor Air Quality, ASHRAE Standard 62-1981, American Society of Heating, Refrigeration and Air Conditioning Engineers, Inc., Atlanta (1981).

4. Proposed Cleanup Standards for Inactive Uranium Processing Sites, U.S. Environmental Protection Agency, Federal Register, 45:27370 (April 1980).

5. Indoor Radiation Exposure Due to Radium-226 in Florida Phosphate Land: Radiation Protection Recommendations and Request for Comment, U.S. Environmerital Protection Agency, Federal Register, 44: 38664 (July 1979).

6. Final Environmental Impact Statement for Expanded Bonneville Power Administration Residential Weatherization Program, U.S. Dept. of Energy Report DOE/EIS-0095F (Sept. 1984).

7. Exposures from the Uranium Series with Emphasis on Radon and Its Daughters, National Council on Radiation Protection and Measurements Report 77, Bethesda, Md. (March 1984).

8. Regulations and Standards Applicable to Metal and Nonmetal Mining and Milling Operations, U.S. Mine Safety and Health Administration, 30 CFR Parts 57.5.38 and 57.5-39 (July 1, 1979). 
9. Radon is a Hot Issue for the Phosphate Industry, Chemical Week, pp. 39-41 (Sept. 1986).

10. Hanson, D.J., High Radon Levels in Homes Spark Moves to Combat Pollutant, Chemical and Engineering News, pp. 18-19 (Nov. 18, 1985).

11. R. Toohey, Argonne National Laboratory, personal communication (1986).

12. Information Sheet on Indoor Radon, U.S. Environmental Protection Agency, Washington, D.C. (Jan. 1985).

13. Medora, R., and M. Trefler, Methods for Measuring Indoor Radon Levels in a Structure Built with Phosphogypsum, in Indoor Radon - Proc. of an APCA Specialty Conf., Air Pollution Control Assn., Pittsburgh (1986).

14. Pensko, J., Z. Stpiczynska, and K. Blaton-Albicka, Emanating Power of Radon-222 Measured in Building Materials, in Natural Radiation Environment III, Vol. 2, T.F. Gesell and W.M. Lowder, eds., Technical Information Center, U.S. Dept. of Energy (1980).

15. Moeller, D.W., D.W. Underhill, and G.V. Gulezian, Population Dose Equivalent from Naturally Occurring Radionuclides in Building Materials, in Natural Radiation Environment III, Vol. 2, T.F. Gesell and W.M. Lowder, eds., Technical Information Center, U.S. Dept. of Energy (1980).

16. Henschel, D.B., and A.G. Scott, The EPA Program to Demonstrate Mitigation Measures for Irdoor Radon: Initial Results, in Indoor Radon - Proc. of an APCA Specialty Conf., Air Pollution Control Assn., Pittsburgh (1986).

17. Wellfurd, B.W., Mitigation of Indoor Radon Using Balanced Mechanicai Ventilation, in Indoor Radon - Proc. of an APCA Specialty Conf., Air Pollution Control Assn., Pittsburgh (1986).

\section{BIBLIOGRAPHY}

Cohen, N., Measurement Methodologies, Proc. New York Governor's Conf. on Indoor Radon, March 1986, New York University (in press).

Evaluation of Occupational and Environmental Exposures to Radon and Radon Daughters in the United States, National Council on Radiation Protection and Measurements Report 78, Bethesda, Md. (May 31, 1984).

George, A.C., Instruments and Methods for Measuring Indoor Radon and Radon Progeny Concentrations, in Indoor Radon - Proc. of an APCA Specialty Conf., Air Pollution Control Assn., Pittsburgh (1986). 
Standards for Remedial Actions at Inactive Uranium Processing Sites, U.S. Environmental Protection Agency, 40 CFR Part 192, Federal Register, 48(3): 590-605 (Jan. 5, 1983).

Toohey, R.E., Measurement Instrumentation, Proc. New Yorik Governor's Conf. on Indoor Radon, March 1986, New York University (in press).

\section{APPENDIX:}

\section{INHALATION DOSE FROM RADON DECAY PRODUCT: 205}

The highest levels of radon decay products observed during the radiological surveys of the Raritan Depot were measured in Bldg. 205, and the maximum values measured by both EPA and NUS corresponded to approximately $0.08 \mathrm{WL}$. To evaluate dose (that is, integrated exposure to this radiation), we will convert to the unit of exposure, working level month (WLM), defined as exposure for $170 \mathrm{~h}(4.33 \mathrm{wk}$ at $40 \mathrm{~h} / \mathrm{wk})$ to $1 \mathrm{WL}$ of radon daughters:

$$
0.08 \text { WL } \times \frac{24 \times 365}{170}=4.12 \text { WIM }
$$

To evaluate the dose to the bronchial epithelum (the lung tissue), we introduce the conversion factor $0.5 \mathrm{rad} / \mathrm{WLM}$ to obtain the dose to the nasal epithelum, and a quality factor of 20 for alphe particles:

$$
\text { 4.i WLM } \times 0.5 \frac{\mathrm{rad}}{W L M} \times 20 \frac{\mathrm{rem}}{\mathrm{iad}}=41.2 \mathrm{rem}
$$

To convert the lung dose to the whole-body equivalent, the International Commission on Radiological Protection (ICRP) weight factor of 0.12 is used:

$$
41.2 \mathrm{rem} \times 0.12=4.94 \frac{\mathrm{rem}}{\mathrm{yr}}
$$

Thus, the annual dose for occupants of Bldg. 205 (calculated on the basis of $24-\mathrm{h} / \mathrm{day}$ exposure) would be nearly 5 rem. Based on a 40-h working week instead of full-time exposure, the corresponding annual dose would be $1.2 \mathrm{rem}$. 